\title{
Genotypic richness predicts phenotypic variation in an endangered clonal plant
}

Suzanna M Evans, Elizabeth A Sinclair, Alistair G B Poore, Keryn F Bain, Adriana Vergés

Declines in genetic diversity within a species can affect the stability and functioning of populations. The conservation of genetic diversity is thus a priority, especially for threatened or endangered species. The importance of genetic variation, however, is dependent on the degree to which it translates into phenotypic variation for traits that affect individual performance and ecological processes. This is especially important for predominantly clonal species, as no single clone is likely to maximise all aspects of performance. Here we show that intraspecific genotypic diversity as measured using microsatellites is a strong predictor of phenotypic variation in morphological traits and shoot productivity of the threatened, predominantly clonal seagrass Posidonia australis, on the east coast of Australia. Biomass and surface area variation was most strongly predicted by genotypic richness, while variation in leaf chemistry (phenolics and nitrogen) was unrelated to genotypic richness. Genotypic richness did not predict tissue loss to herbivores or epiphyte load, however we did find that increased herbivore damage was positively correlated with allelic richness. Although there was no clear relationship between higher primary productivity and genotypic richness, variation in shoot productivity within a meadow was significantly greater in more genotypically diverse meadows. The proportion of phenotypic variation explained by environmental conditions varied among different genotypes, and there was generally no variation in phenotypic traits among genotypes present in the same meadows. Our results show that genotypic richness as measured through the use of presumably neutral DNA markers does covary with phenotypic variation in functionally relevant traits such as leaf morphology and shoot productivity. The remarkably long lifespan of individual Posidonia plants suggests that plasticity within genotypes has played an important role in the longevity of the species. However, the strong link between genotypic and phenotypic variation suggests that a range of genotypes is still the best case scenario for adaptation to and recovery from predicted environmental change. 


\section{Genotypic richness predicts phenotypic variation in an endangered}

2

3 Suzanna M. Evans ${ }^{*}$ a,b , Elizabeth A. Sinclair ${ }^{\mathrm{c}, \mathrm{d}}$, Alistair G. B. Poore ${ }^{\mathrm{b}}$, Keryn F.

11 Word count: 8467

12 Running title: Genetic diversity and trait variation in seagrass 


\section{Abstract}

17 Declines in genetic diversity within a species can affect the stability and functioning of

18 populations. The conservation of genetic diversity is thus a priority, especially for threatened or

19 endangered species. The importance of genetic variation, however, is dependent on the degree to

20 which it translates into phenotypic variation for traits that affect individual performance and

21 ecological processes. This is especially important for predominantly clonal species, as no single

22 clone is likely to maximise all aspects of performance. Here we show that intraspecific genotypic

23 diversity as measured using microsatellites is a strong predictor of phenotypic variation in

24 morphological traits and shoot productivity of the threatened, predominantly clonal seagrass

25 Posidonia australis, on the east coast of Australia. Biomass and surface area variation was most

26 strongly predicted by genotypic richness, while variation in leaf chemistry (phenolics and

27 nitrogen) was unrelated to genotypic richness. Genotypic richness did not predict tissue loss to

28 herbivores or epiphyte load, however we did find that increased herbivore damage was positively

29 correlated with allelic richness. Although there was no clear relationship between higher primary

30 productivity and genotypic richness, variation in shoot productivity within a meadow was

31 significantly greater in more genotypically diverse meadows. The proportion of phenotypic

32 variation explained by environmental conditions varied among different genotypes, and there

33 was generally no variation in phenotypic traits among genotypes present in the same meadows.

34 Our results show that genotypic richness as measured through the use of presumably neutral

35 DNA markers does covary with phenotypic variation in functionally relevant traits such as leaf

36 morphology and shoot productivity. The remarkably long lifespan of individual Posidonia plants

37 suggests that plasticity within genotypes has played an important role in the longevity of the

38 species. However, the strong link between genotypic and phenotypic variation suggests that a 
39 range of genotypes is still the best case scenario for adaptation to and recovery from predicted

40 environmental change.

41 Key-words clonality, genotypic diversity, Posidonia australis, productivity, seagrass

\section{Introduction}

43 The link between biodiversity and ecosystem function is well-established at the species level,

44 with communities that support a wide range of species often better able to stabilise multiple

45 ecosystem processes in response to disturbance or change than species poor communities

46 (Loreau et al. 2001; Hooper et al. 2005; Stachowicz et al. 2007; Tilman et al. 2012; Cardinale et

47 al. 2013; Lefcheck et al. 2015). Similarly, genetic diversity within species, as measured by the

48 number of genotypes, can enhance productivity (Aguirre and Marshall 2012), increase resilience

49 (Massa et al. 2013) and have cascading benefits to the surrounding ecosystem (Hughes et al.

50 2008; Ellers 2009). The importance of genetic variation to ecosystem functioning, however,

51 depends on the degree to which it translates into variation in traits that affect the functioning of

52 individuals, and upon which natural selection can act (Foster Huenneke 1991; Vasemägi and

53 Primmer 2005; Bolnick et al. 2011). Therefore, it is necessary to quantify the degree of

54 phenotypic variation among genotypes within species to better predict how loss of genotypes can

55 affect the performance of populations (Lande and Shannon 1996; Ellers 2009; Forsman and

56 Wennersten 2015), particularly during periods of changing climatic conditions and increased

57 anthropogenic stressors (Best et al. 2015).

58 The conservation of genetic diversity is a priority for the management of threatened or

59 endangered species, with the aim of maintaining evolutionary viability by maximising the

60 chances of persistence in the face of environmental change (Foster Huenneke 1991; Reed and

61 Frankham 2003; Hughes et al. 2008). For species that have naturally low levels of genetic 
62 variation due to predominantly clonal life history strategies, differences in functioning among the

63 few genotypes present becomes especially important. It may be that only the most diverse

64 assemblage will be able to maximise multiple ecosystem functions (Duffy et al. 2003), which

65 suggests that a loss in diversity may significantly influence ecosystem properties. The theory

66 that higher species diversity benefits ecosystem 'multifunctionality' stems from the observation

67 that species that do not contribute to one ecosystem process often play an important role in a 68 separate process and/or under different conditions (Bradford et al. 2014; Byrnes et al. 2014;

69 Lefcheck et al. 2015). Similarly, it is highly unlikely that any single genotypic clone, no matter

70 how well-adapted, would be able to capitalise on all aspects of performance. Rather, it is 71 expected that multiple genotypes will contribute to multiple different processes and/or thrive 72 under different conditions.

73 While clonal species may be associated with lower genetic diversity, there are a number of 74 benefits that result from clonal reproduction in plant species. For example, clones are able to 75 translocate resources between connected ramets - potentially increasing the allocation of limiting 76 resources to the tissues in which they are scarce, thus increasing the survival and distribution of 77 the genet (Alpert and Stuefer 1997). Although this strategy may increase plant performance 78 under many conditions, physical disturbance, fragmentation, and pathogens can cut off transport 79 between ramets and potentially wipe out entire genets that are not adapted to these stressors 80 (Callaghan et al. 1992; Honnay and Bossuyt 2005). For populations in stable environments (i.e., 81 biotic and/or abiotic conditions remain constant), differences in the success of particular 82 genotypes, as well as genetic drift, can lead to an overall decrease in genet number over time and 83 the dominance of one or a few clones (McLellan et al. 1997; Eckert 2002; Balloux et al. 2003). 84 In changing environments, however, persistence should be enhanced by the maintenance of 
85 genetic variation via occasional seed production or the recruitment of new sexually produced

86 individuals (Eckert 2002; Honnay and Bossuyt 2005). Otherwise, the population is assumed to

87 be at much greater risk of extinction if environmental conditions change, compared to a 88 genetically diverse population of conspecifics. In this study, we examine the relationship

89 between genetic diversity, variation in phenotype, and ecosystem processes in predominantly

90 clonal, threatened seagrass meadows that range from near-monoclonal to genotypically diverse.

91 Seagrasses are a major source of primary productivity supporting food webs globally (Mateo et

92 al. 2006; Hughes et al. 2009), with an estimated value of over \$US28, 000 ha $^{-1}$ year-1 (adjusted

93 for inflation; Costanza et al. 1997). Seagrass meadows also act as significant 'blue carbon' stores

94 (Fourqurean et al. 2012) and have cascading benefits to surrounding ecosystems (Duffy 2006;

95 Barbier et al. 2011). Unfortunately, seagrasses are rapidly declining worldwide and are now rated

96 amongst the most threatened ecosystems on the planet (Waycott et al. 2009). Over the past

97 decade, manipulations of genotypic diversity and identity in Zostera marina seagrass meadows

98 from the Northern Hemisphere have shown that increasing the number of genotypes within an

99 experimental plot can enhance resistance to disturbance by grazers (Hughes and Stachowicz

100 2004), influence grazer biomass (Hughes et al. 2010), and result in greater shoot densities and

101 biomass compared to monocultures during disturbance events (Reusch et al. 2005; Hughes and

102 Stachowicz 2011). Experimental manipulations of clonal identity have shown wide variation in

103 biomass production and herbivore susceptibility among individual genotypes that can be similar

104 in magnitude to the variation caused by environmental factors (e.g. nitrogen loading; Tomas et

105 al. 2011). The positive effects of higher genotypic richness can be attributed to a combination of

106 (i) complementarity among individual genotypes, in which the environment is exploited more

107 efficiently by including a wider variety of functionally important phenotypes, and (ii) the 
108 sampling effect, in which there is simply a statistically higher probability of selecting pre-

109 adapted phenotypes from a more diverse group (Hughes et al. 2008; Hughes and Stachowicz

110 2011; Forsman and Wennersten 2015). However, despite the obvious link between genotypic

111 diversity and the performance and functioning of seagrass meadows, there is a lack of

112 information regarding the mechanisms by which this relationship occurs.

113 The majority of studies that have manipulated genotypic diversity in seagrass meadows have

114 identified genotypes using allozymes or microsatellite DNA markers that are presumed to be

115 selectively neutral (Reusch 2001). As such, the ecological effects of these genotypic

116 manipulations will depend on the relationship between these neutral markers and phenotypic

117 variation (Hughes et al. 2008). Although it is frequently assumed that a greater diversity of

118 phenotypic traits related to ecosystem function (e.g. variation in height or biomass) directly

119 results from corresponding genetic diversity, this relationship is rarely directly tested (excluding

120 some well-studied terrestrial examples from Populus hybrid complexes, e.g., Whitham et al.

121 2006). However, in cases where the conservation of a species may be dependent on the ability to

122 respond positively to stress and adapt to new and potentially challenging conditions, variation in

123 both genotype and phenotype needs to be considered (Hughes 2014).

124 On the east coast of Australia, meadows of the temperate seagrass species Posidonia australis

125 Hook. $f$. vary widely in genetic diversity; from predominantly clonal to moderate genetic

126 diversity (with sexual reproduction; Evans et al. 2014). As such, it provides an ideal model

127 ecosystem to explore whether genetic diversity can predict variation in phenotypic and

128 ecosystem processes. The rapid decline in Posidonia australis meadows associated with human

129 population growth and urbanisation (NSW DPI 2012; West 2012) has increased the need to

130 identify mechanisms behind variation in meadow form and function, so that we can better tailor 
131 our efforts to identify meadows at risk of extinction, as well as more successful avenues for

132 restoration.

133 In this study, we quantified the relationship between genotypic richness and traits of Posidonia

134 australis that are considered functionally important at the ecosystem level; plant productivity,

135 leaf structure and chemistry, epiphyte load, and tissue loss to herbivory. Structural leaf traits

136 (morphology, biomass and shoot density) provide a measure of habitat structure and complexity

137 (Middleton et al. 1984). They also influence trophic interactions by providing shelter for both

138 predators and prey (Farina et al. 2009) and are known to change in response to environmental

139 stressors (Waycott et al. 2005). Leaf chemical constituents such as nitrogen and phenols affect

140 decomposition rates and photosynthetic capacity (Harrison 1989; Alcoverro et al. 2001) and

141 influence susceptibility to grazing (Goecker et al. 2005; Vergés et al. 2007). Elevated epiphyte

142 loads have been linked to human-induced eutrophication, can be potentially fatal to seagrasses by

143 reducing light availability (Borowitzka et al. 2006), and are thus considered important indicators

144 of ecosystem health (Wood and Lavery 2000). Finally, tissue loss to herbivores is an important

145 process that transfers energy to higher trophic levels and can influence the distribution and

146 growth patterns of seagrasses (Valentine and Duffy 2006). More specifically, our study

147 addressed the following questions:

148 1. Does genotypic diversity in P. australis meadows predict phenotypic variation?

1492 2. Are genotypically diverse meadows more productive?

1503 . Is genotypic diversity related to herbivory/epiphyte load?

151 4. What is the relative importance of genotypic identity and the environment in explaining $152 \quad$ phenotypic variation? 


\section{Materials and methods}

\section{Study species and location}

156 Posidonia australis is a long-lived, slow-growing seagrass endemic to the temperate Australian

157 coastline (Gobert et al. 2006). It is considered one of the most structurally complex seagrasses

158 (Middleton et al. 1984) and provides food and refuge for a range of commercially important fish

159 and invertebrate species (Gobert et al. 2006). Posidonia australis is in rapid decline, particularly

160 on the eastern coastline of Australia, where it has been formally listed as endangered in six

161 estuaries (NSW Fisheries Scientific Committee 2010). In 2011, 360 individual shoots were

162 collected from 12 geographically distinct meadows $(n=30$ per meadow $)$ across New South

163 Wales (NSW) on the east coast of Australia, including the extreme northern range-edge of the

164 species (Fig. 1). Shoots were collected once every $2-3 \mathrm{~m}$ along a linear transect, to reduce the

165 chances of resampling the same genetic individual (Evans et al. 2014). Sample collections were

166 supported by a NSW Department of Primary Industries Scientific Collection Permit (P11/0059-

167 1.2)

168 Genetic diversity

169 Immediately after collection, shoots were placed on ice and returned to the laboratory. A set of

170 eight polymorphic microsatellite markers (developed by Sinclair et al. 2009) were used to

171 determine levels of genetic diversity within and among the 12 P. australis meadows sampled.

172 Following amplification (see Evans et al. 2014 for full protocol), multiple PCR products were

173 combined where possible (pre-determined by size and label) and run on a CEQ 8800 Genetic

174 Analysis System (Beckman Coulter). Size standard 400 was used to determine allele sizes, which

175 were then scored using the Beckman Coulter software. The number of unique multilocus

176 genotypes (MLGs) and alleles per meadow were estimated using GenClone 2.0 (Arnaud-Haond 
177 and Belkhir 2007), as well as the likelihood of individual genotypes arising through sexual

178 recombination given allelic frequencies in the regional population $\left(\mathrm{P}_{\mathrm{gen}}\right)$. Allelic richness ranged

179 from 10 to 20 alleles per meadow, while genotypic richness ranged from as few as two MLGs

180 per meadow (near-monoclonal) through to 21 MLGs per meadow (high diversity). In total, 79

181 unique MLGs were identified from the 360 shoots sampled. Of these, seven MLGs were shared

182 across two or more meadows (Table 1), while the remainder were unique to their sample

183 locations. For all genotypes $\mathrm{P}_{\text {gen }}$ was $<0.02$, allowing us to conclude that individual shoots

184 sharing the same genotype are highly unlikely to have arisen through sexual recombination

185 (Arnaud-Haond and Belkhir 2007).

\section{Phenotypic diversity}

187 Shoots collected for genotyping were measured for traits relating directly to the shoot phenotype

188 (leaf surface area, biomass, nitrogen content, and total phenolics), as well as traits considered

189 important for ecosystem functioning (productivity, herbivory, and epiphyte biomass). In

190 addition, shoot density and herbivorous fish counts were done within each meadow.

191 In the laboratory, epiphytes were carefully removed from the leaves with a razor blade. While

192 some shoots retained small quantities of encrusting epiphytes on the oldest leaves, this did not

193 impact morphometric measurements, and these leaves were not included in chemical analyses.

194 Morphometric measurements were made on all leaves present (generally between 2-5 leaves per

195 shoot), from the ligule to the leaf tip. Surface area of all leaves was calculated as $\mathrm{mm}^{2}$ shoot $^{-1}$,

196 minus any damage due to herbivory. The leaf biomass (mg shoot $\left.{ }^{-1}\right)$ of each shoot was determined

197 by removing the leaves at the ligule, freeze-drying and then weighing. Any attached rhizome was

198 not included as the amount collected varied widely between shoots. Meristematic tissue below

199 the ligule was also excluded as this was removed for DNA analysis. 
200 Shoot density was determined in situ using a $0.25 \mathrm{~m}^{2}$ quadrat in which all individual shoots were

201 counted. The quadrat was haphazardly distributed ten times within each meadow to obtain a

202 mean shoot density per meadow. Quadrat data were recorded at the same time and within the

203 same meadow area as the genetic sampling. Productivity per shoot was measured with

204 lepidochronology, which uses patterns in the thickness of leaf sheaths retained on the rhizome

205 from old leaves to estimate the rate of new leaf production over time, recorded as dry weight ( $\mathrm{mg}$

206 shoot $^{-1}$ year $^{-1}$ ). This method is considered an accurate way of determining long-term annual

207 productivity of seagrasses in the Posidonia genus (Pergent et al. 1997; Peirano 2002). As our

208 study is concerned with long-term productivity, this method was used in favour of leaf-marking,

209 which provides a snapshot of leaf productivity at the time of sampling (Short \& Duarte 2000).

210 We followed the methods of Pergent et al. (2004), by detaching and numbering the dead leaf

211 sheaths from oldest to youngest and measuring cross sections under the microscope to record the

212 distinct cyclical variations in width (one cycle $=$ one chronological year). Due to the high number

213 of leaf sheaths present on every shoot, a subset of ten shoots per meadow was used to conduct

214 the lepidochronology measures. Primary productivity (PI) was estimated using the formula $P I=$

$215 N \times L \times D$. Where $N$ is the number of leaves produced annually (number of sheaths per cycle), $L$

216 is the mean leaf length and $D$ is the mean leaf density (leaf weight per unit length).

217 Near-infrared reflectance spectroscopy (NIRS) was used to determine the nitrogen content and 218 total phenols within leaf tissues. NIRS is a rapid and inexpensive technique for analysing the

219 composition of organic tissue (Foley et al. 1998), and has been used to effectively predict

220 nitrogen and phenolic content in Posidonia australis (Bain et al. 2013) and macroalgae (Hay et

221 al. 2010). NIRS works by irradiating a sample and measuring the absorbance over a series of

222 wavelength intervals, resulting in a spectrum that characterises the chemical composition of the 
223 sample. Quantifying a specific plant trait then depends on constructing a statistical model that

224 calibrates the spectral properties of a sample with the laboratory derived values determined for

225 the trait of interest (Foley et al. 1998); in this case, nitrogen content and total phenols. Samples

226 were processed and spectra were collected following the methods outlined in Bain et al. (2013).

227 Prediction models were developed by calibrating NIRS spectra from a subset of samples against

228 laboratory reference values using WinISI ${ }^{\mathrm{TM}}$ III software (Infrasoft International, State College,

229 PA). Reference values for nitrogen content were determined by combustion using a CHN

230 analyser (TruSpec ${ }^{\circledR}$ Micro Series, Michigan). The concentration of total phenols was obtained

231 colorimetrically using the Folin-Ciocalteu's method (Singleton et al. 1999; Ainsworth and

232 Gillespie 2007) with a gallic acid standard. Prediction models from Bain et al. (2013) for $P$.

233 australis were then used to estimate nitrogen $\left(\%\right.$ dry weight, model $\left.\mathrm{R}^{2}=0.95\right)$ and total phenols

234 (gallic acid equivalent (GAE) \% dry weight, model $\mathrm{R}^{2}=0.92$ ) in the full set of samples.

235 Herbivory was measured indirectly on each shoot as the area of leaves missing due to herbivore

236 damage $\left(\mathrm{mm}^{2}\right.$ shoot $\left.^{-1}\right)$. Missing leaf tips were not included in these calculations as we were

237 unable to distinguish between area lost due to damage sustained during harvesting or storm

238 activity/erosion and true herbivory.

239 To assess whether differences in tissue loss to herbivory were explained by differences in

240 herbivore abundance among sites (rather than seagrass traits), herbivore abundance was

241 measured within each of the 12 meadows using a combination of three methods: visual transects

242 (Greene and Alevizon 1989), beach seine netting (Connolly 1994), and benthic sleds (Colman

243 and Segrove 1955). Each method was replicated three times per meadow. Visual transects were

244 conducted via snorkel, swimming in a straight line for $50 \mathrm{~m}$ (marked with weighted measuring

245 tape). All fish within $2 \mathrm{~m}$ on either side of the measuring tape were recorded. A benthic sled was 
246 towed by hand along the seagrass canopy at a constant depth of $1 \mathrm{~m}$. The trawls were $100 \mathrm{~m}$ in

247 length and were towed for approximately 3.5 min (a speed of about 1 knot depending on

248 prevailing conditions). The trawl frame consisted of a stainless steel sled with an opening frame

249 measuring $80 \times 40 \mathrm{~cm}$. This was attached to a conical net measuring $2.4 \mathrm{~m}$ in length, with the

$250 \mathrm{cod}$ end tapering to $105 \mathrm{~mm}$ in diameter (securely fastened during each trawl). Each trawl was

251 hauled by one person at the end of a long tow rope in a line parallel to the shore (see Colman and

252 Segrove 1955). The beach seine net used was $20 \mathrm{~m}$ in length ( $3 \mathrm{~m}$ cod end) with a $2 \mathrm{~m}$ drop. The

253 net was towed through $1 \mathrm{~m}$ of water directly over the seagrass canopy by two people standing

254 parallel to the shore for a distance of $50 \mathrm{~m}$. Nets for both the benthic sled and beach seine were

255 made from $5 \mathrm{~mm}$ mesh. All fish caught in the nets were photographed for later identification and

256 returned to the water. Herbivorous fish abundance per meadow was then standardised using

257 catch per unit effort (CPUE).

\section{Statistical analyses}

259 The coefficient of variation (CV) was used to quantify variation in the phenotypic traits, given

260 that they were measured using different units and had widely different means, where the

261 coefficient of variation, $\mathrm{CV}$, is the standard deviation divided by the mean for each trait within

262 each meadow. This standardised level of variation across all traits allowed contrasts to be made

263 between phenotypic diversity (mean CV across all traits) and genotypic richness (number of 264 MLGs).

265 Linear regression was used to determine whether genotypic richness could predict the variation

266 in phenotypic traits (as measured by the CV for surface area, shoot biomass, productivity,

267 phenolics, nitrogen, herbivory and epiphyte biomass). For each trait, the mean CV ( \pm SE) across

268 shoots within a meadow was used. Linear regression analyses were also used to determine 
269 potential relationships between genotypic richness and average values for the aforementioned

270 phenotypic traits. To ensure that a linear relationship was the most appropriate fit for the data, we

271 used Akaike's information criterion to compare the best-fit of linear, polynomial and logarithmic

272 regressions.

273 It is important to note that that an interdependency may exist between genotypic and allelic

274 richness when attempting to estimate the importance of genetic diversity, particularly at low

275 genotypic richness levels (Massa et al. 2013). As such, we ran additional linear regression

276 analyses to explore potential relationships between allelic richness per meadow and phenotypic

277 trait means and variation.

278 To investigate the proportion of phenotypic variation explained by genotypic identity and the

279 environment, we compared (i) variation within and among replicate genotypes in individual

280 meadows, and (ii) variation within and among meadows in MLGs occurring across more than

281 one location. Although we found seven MLGs that were shared across two or more sites (Table

282 1), only two of these MLGs ('Genotype A' and 'Genotype C') had enough replicates both within

283 and across meadows to compare this variation with sufficient statistical power. We used a series

284 of one-way ANOVAs to compare variation within Genotypes 'A' and ' $\mathrm{C}$ ' across the two

285 meadows in which each occurred (Genotype A in Lake Macquarie/Wallis Lake, and Genotype C

286 in Port Stephens/Pittwater) to determine the amount of phenotypic variation explained by

287 environment (meadow). As genotypes ' $A$ ' and ' $C$ ' were not found in the same locations, a

288 factorial ANOVA testing for the effect of genotype, environment and genotype by environment

289 interactions was not possible. The meadows at Port Stephens and Pittwater each contained

290 enough individual replicated genotypes to compare how phenotypic traits varied within and

291 among different MLGs in the same meadow. In this way we could determine the amount of 
292 phenotypic variation explained by genotype not confounded by differences in the environment.

293 Again, separate analyses had to be used for the two meadows as these genotypes were not shared 294 across locations.

\section{Results}

296 Positive linear relationships were found between the number of genotypes per meadow and the

297 mean of the coefficient of variation for four traits (surface area, biomass, productivity and 298 epiphyte load). Considering each trait alone, the strongest positive linear relationship was

299 between genotypic richness and variation in surface area (Fig. 2a). Similarly, greater variation in

300 biomass per shoot was significantly related to high genotypic richness (Fig. 2b). There were no

301 significant relationships between genotypic richness and variation in nitrogen content or total

302 phenols (Fig. 2c). The relationship between mean shoot density and genotypic richness was also 303 not significant (Fig. S1).

304 Meadows with greater genotypic richness did not show significantly greater productivity per 305 shoot on average (Fig. S1). However, there was a positive linear relationship between genotypic 306 richness and variation in shoot productivity (Fig. 3a), denoting a greater range of productivity 307 values in the meadows with more genotypes. To test whether the meadows with greatest 308 numbers of genotypes showed greater capacity for high shoot productivity, we performed a 309 quantile regression on the raw productivity data (Fig. S2). We detected no significant increase in

310 the highest levels of shoot productivity (values in the $90^{\text {th }}$ percentile) with greater genotypic

311 richness, but did detect a negative relationship between genotypic richness and the likelihood of

312 having low productivity shoots (the $10^{\text {th }}$ percentile; Fig. S2). 
313 Of the community traits measured, a significant linear relationship was found between genotypic

314 richness and variation in epiphyte biomass (Fig. 3b). Genotypic richness and mean herbivory

315 levels showed no significant linear relationship (Fig 3c). While there were no significant non-

316 linear relationships found either, there is a clear increase in mean herbivory with genotypic

317 richness up to 14 genotypes, after which there is a drop in mean herbivory to near zero at the

318 highest level of diversity (21 genotypes, Fig. 3c). This is not a direct result of the number of

319 herbivores per meadow (rather than genotypes) as the relationship between herbivore abundance

320 (CPUE) and mean herbivory (Fig. S3) does not match that between herbivory and genotypic

321 richness (Fig. 3c). This relationship was also tested using the diversity (Shannon diversity index)

322 of herbivorous fish and mean herbivory, and the result was also non-significant $\left(\mathrm{R}^{2}=0.01, P=\right.$

323 0.78). As epiphytic biomass may be related to levels of herbivory (Heck and Valentine 2006), the

324 relationship between these variables was also explored. However, there was no relationship

325 between tissue loss to herbivory and epiphyte load $\left(\mathrm{R}^{2}=0.14, P=0.24\right)$, nor was there a

326 relationship between the abundance of herbivorous fish and epiphyte load $\left(\mathrm{R}^{2}=0.05, P=0.47\right)$.

327 There were no significant linear relationships between the mean values of each phenotypic trait

328 measured and genotypic richness. That is, despite significant relationships between genotypic

329 richness and variation in some plant traits, shoots were not significantly larger on average in

330 meadows with more genotypes, nor did they grow more densely (Fig. S4).

331 Additional linear regression analyses were conducted to explore potential relationships between

332 allelic richness per meadow and phenotypic trait means and variation. There were no significant

333 relationships observed between allelic richness and variation in any of the traits measured.

334 Similarly, there were no significant relationships observed between allelic richness and trait 
335 means, with the exception of mean tissue lost to herbivory, which significantly increased with

336 increasing allelic richness $\left(\mathrm{R}^{2}=0.39 ; P=0.03\right.$; Fig. S5).

337 Environment (i.e. meadow) explained between 16-33\% of phenotypic variation in the two MLGs

338 that occurred across two geographically distinct meadows (Table 2; 'Genotype A' occurring in

339 both Wallis Lake and Lake Macquarie, and 'Genotype C' occurring in both Port Stephens and

340 Pittwater; Table 1). For Genotype A, there were significant differences between meadows in

341 surface area, biomass, leaf nitrogen content and epiphyte load across the two locations. For

342 Genotype $\mathrm{C}$, the results revealed no significant differences in any of the phenotypic traits

343 measured for this genotype (Table 2a), with the exception of biomass, which was significantly

344 lower in Pittwater than in Port Stephens $\left(F_{1,20}=9.51, P=0.005\right)$.

345 When contrasting genotypes within the two meadows with multiple, replicated genotypes (Port

346 Stephens and Pittwater), we found no significant differences among genotypes, except for total

347 phenolics in Port Stephens (Table $2 \mathrm{~b} ; F_{3,22}=4.67, P=0.011$ ). In that case, approximately $39 \%$

348 of the variation observed was explained by genotype.

\section{Discussion}

350 Our results clearly demonstrate that intraspecific genotypic diversity is a strong predictor of 351 phenotypic variation in multiple functionally important traits of the endangered clonal seagrass,

352 Posidonia australis. Genotypic richness most strongly predicted variation in morphological traits

353 (surface area and biomass), as well as variation in shoot productivity of individual seagrass 354 meadows.

355 Genetic variation should only be advantageous to a population if it translates into phenotypic 356 variation; the raw material for evolution by natural selection (Foster Huenneke 1991). Although 
357 the microsatellite loci used in this study are assumed to come from non-coding (neutral) regions

358 of the genome, our results suggest that these genetic markers adequately reflect variation in 359 genes coding for quantitative traits, such as leaf morphology and productivity. This variation

360 should be especially important for predominantly clonal species like $P$. australis because it is

361 highly unlikely that a single clone would be able to capitalise on all levels of performance.

362 Rather, it is more likely that individual genotypes that do not contribute to one ecosystem

363 process may play an important role in a separate process and/or under different conditions (as

364 observed in studies of species diversity; Duffy et al. 2003; Bradford et al. 2014; Byrnes et al.

365 2014; Lefcheck et al. 2015). Correspondingly, our results suggest that a variety of genotypes and

366 corresponding phenotypes is the best case scenario for adaptive capacity in terms of both

367 responding to change and recovering from disturbance (Hughes and Stachowicz 2004; Reusch et

368 al. 2005; Ehlers et al. 2008; Hughes and Stachowicz 2011; Hughes 2014).

369 Our original hypothesis that average productivity would be higher in more diverse meadows was

370 based on results from a number of similar studies linking genotypic diversity to plant production

371 (Hughes and Stachowicz 2004; Reusch et al. 2005; Crutsinger et al. 2006; Kotowska et al. 2010;

372 Hughes and Stachowicz 2011; Drummond and Vellend 2012). However, we did not find a clear

373 relationship between mean shoot productivity and genotypic richness. Interestingly, we found

374 that the variation of productivity values was significantly greater in more genotypically diverse

375 meadows (Fig. 3a). While productivity was more variable, we did not find that the capacity for

376 high shoot productivity was any greater in meadows with more genotypes (i.e. the highest values

377 of productivity in these meadows were no higher than those in meadows with few genotypes).

378 These results may be reflecting a sampling effect (Wardle 1999), meaning that there is a higher

379 probability of selecting a wider variety of phenotypes from a more diverse group (Hughes et al. 
380 2008; Forsman and Wennersten 2015). As such, we may expect that, on average, populations

381 with a higher genetic diversity may be more likely to include genotypes with a wider range of

382 productivity values (both higher and lower than the expected average).

383 The relationship between genotypic richness and tissue loss to herbivory appeared to be non-

384 linear, with the greatest amount of herbivore damage occurring at intermediate levels of

385 genotypic richness, after which there is a marked drop in herbivory at the meadow of highest

386 diversity (St. Georges Basin; 21 MLGs). This drop in herbivory is consistent with studies that

387 report a greater resistance to herbivory in more genotypically diverse plant communities (Hughes

388 and Stachowicz 2004; McArt and Thaler 2013). While we did not find any significant

389 relationships between genotypic richness and herbivory, we did find a positive linear relationship

390 between allelic richness and herbivory. This discrepancy between diversity measures can be

391 attributed to the meadow at St. Georges Basin, which had the highest genotypic richness of all

392 meadows sampled, but had intermediate allelic richness (15 alleles per meadow), compared to

393 other locations which had up to 20 alleles per meadow (Pambula Lake, Sydney Harbour and Port

394 Hacking). The interdependent relationship between allelic richness and genotypic richness is

395 considered important in the context of resilience and adaptive capacity of seagrasses (Massa et

396 al. 2013; Jahnke et al. 2015), and the effects of these two sources of genetic diversity are often

397 hard to disentangle at low levels of genotypic richness (Massa et al. 2013). Overall, our results

398 suggest that an increase in genetic diversity is related to increased tissue loss to herbivory.

399 Similar findings of increased host plant genetic diversity influencing levels of herbivore damage

400 have been reported for experimental manipulations of terrestrial plants (e.g. Castagneyrol et al.

401 2012; Barton et al. 2015). In these examples, it was concluded that complementarity among

402 genotypes, rather than the selection effect, was the mechanism behind increased insect herbivory 
403 in genetically diverse plots, with assemblages of different genotypes benefiting polyphagous

404 herbivores (Castagneyrol et al. 2012), and different feeding guilds (Barton et al. 2015). In both

405 cases, genetic diversity was a poor predictor of herbivore abundance.

406 It is commonly observed that epiphytic biomass may be related to herbivory in seagrass beds

407 (Heck and Valentine 2006), but our data showed that neither the amount of leaf tissue lost to

408 herbivory, nor the number of herbivorous fish were related to epiphyte load. A positive

409 relationship was found between genotypic richness and variation in epiphyte load, however, this

410 relationship appears to be strongly influenced by a single site (St. Georges Basin). This

411 relationship should therefore be interpreted with caution, particularly given the high temporal

412 variability in epiphytic growth at the locations sampled.

413 Seagrasses of the genus Posidonia are considered phylogenetically conservative, with low

414 resolution among the eight Australian species across multiple chloroplast and nuclear coding

415 gene regions (Aires et al. 2011). Despite this, seagrasses within this group are thought to have

416 existed for more than 60 million years (Aires et al. 2011) in highly variable physical conditions

417 around the temperate Australian coastline. The $P$. australis meadows on the east coast of

418 Australia are presumably long-established (since sea levels stabilised $\sim 6500$ years ago following

419 the last glacial maximum), but are highly fragmented and hence unlikely to experience any

420 contemporary gene flow via pollen or seed dispersal (Evans et al. 2014). The clones existing

421 within these locations are thus assumed to be highly plastic and capable of withstanding local

422 environmental changes. Although our study shows that phenotypic variation is greatest in the

423 most genotypically diverse meadows, we also detected some phenotypic variation in meadows

424 that are nearly monoclonal (meadows dominated by a single MLG; Wallis Lake, Lake 
425 Macquarie, Brisbane Water and Jervis Bay), highlighting substantial plasticity within these 426 genotypes.

427 Although phenotypic plasticity is considered a strong predictor of fitness and competitive ability 428 (Callaway et al. 2003; Miner et al. 2005; Stomp et al. 2008), the rate of environmental change 429 experienced by seagrass meadows in the $21^{\text {st }}$ Century is unprecedented (Unsworth et al. 2014), 430 and there are ecological limits to phenotypic plasticity that can impact its adaptive value 431 (Valladares et al. 2007). Moreover, a plastic response to environmental change (e.g. reduced leaf 432 area under low light conditions) may not actually enhance plant fitness and thus may not 433 necessarily be an adaptive response (Schlichting 1986). Predicted rapid environmental change 434 can therefore potentially put vulnerable clonal plants at risk of extinction (Honnay and Bossuyt 435 2005; Jump et al. 2009), and populations with a greater variety of genotypes and corresponding 436 phenotypes would be considered less at risk than populations with low diversity, regardless of 437 plasticity (Forsman and Wennersten 2015).

438 With few genotypes shared across sampling locations, we had a limited ability to quantify the relative importance of genotype and local environmental conditions on phenotypic traits. We

440 could, however, contrast two abundant MLGs ('Genotype A' and 'Genotype C') that were each 441 shared across two meadows (Wallis Lake/Lake Macquarie, and Port Stephens/Pittwater 442 respectively, which in both cases are separated by more than $150 \mathrm{~km}$ ). Given the seed dispersal 443 ecology of $P$. australis, it is considered extremely unlikely that these meadows would experience 444 contemporary gene flow at this distance (Kendrick et al 2012; McMahon et al. 2014). As such, 445 we can be confident that these genotypic clones are most likely to have arisen from common 446 ancestral meadows. While only eight microsatellite loci were used to identify genotypic clones in

447 this study, all loci were highly polymorphic with sufficient power to distinguish individual 
448 genotypes $\left(\mathrm{P}_{\mathrm{gen}}<0.02\right)$. Thus, it is highly unlikely that shared genotypes across geographically

449 distinct meadows are the result of low marker resolution. While we cannot confirm that the full

450 genomes are an exact match without further analyses, we can be certain that these meadows are

451 at the very least, highly related. Our results showed that the highly dominant MLG occurring in

452 both Wallis Lake and Lake Macquarie ('Genotype A') significantly varied in a number of

453 phenotypic traits across the two geographically distinct locations (including leaf surface area,

454 biomass and nitrogen content). Between 16 and $32 \%$ of this variation was explained by

455 'environment' (meadow), suggesting that this genotype is capable of remarkable plasticity.

456 In contrast, the dominant MLG occurring in both Port Stephens and Pittwater ('Genotype C')

457 showed no significant differences across the two meadows for five of the six phenotypic traits

458 measured, suggesting that either this genotype has a lower capacity for phenotypic plasticity, or

459 that the environmental conditions are broadly similar in these two estuaries. This second option

460 is unlikely, given that Pittwater is a highly urbanised meadow with an endangered status and the

461 seagrass meadows are considered in rapid decline (Creese et al. 2009; NSW Fisheries Scientific

462 Committee 2010). Biomass was significantly lower in Pittwater when compared to Port Stephens

463 (despite no significant differences across all different genotypes sampled within each location).

464 Surface area of the leaves for 'Genotype C' was no different in these two locations, so it could be

465 hypothesised that lower leaf biomass in Pittwater results from thinner/structurally weaker leaves,

466 perhaps as a consequence of stress caused by reduced light availability (Ralph et al. 2007).

467 When contrasting genotypes within the two meadows that had several replicate genotypes

468 (Pittwater and Port Stephens), there was no detectable variation in phenotypic traits among

469 genotypes (except phenols at Port Stephens). This suggests that these genotypes express largely

470 similar phenotypes within a meadow. Without transplanting these individual genotypes to other 
471 environments, it is not possible to determine whether this consistency is due to these genotypes

472 having a similar fixed expression of traits, or all having sufficient phenotypic plasticity to

473 express the same trait values in that environment.

474 Conclusion

475 Our results indicate that phenotypic diversity in populations of Posidonia australis increases

476 significantly with increased genotypic diversity (MLG). This suggests that the use of presumably

477 neutral DNA markers to measure genetic diversity also adequately reflects variation in several

478 selectively relevant genes coding for quantitative traits, such as leaf morphology and

479 productivity. Despite evidence of remarkable plasticity within genotypes of $P$. australis, an

480 increase in the variation of functionally relevant traits is expected to be advantageous in the face

481 of environmental change.

\section{Acknowledgements}

483 This research was undertaken with the support of an Australian Postgraduate Award at the 484 University of New South Wales. The genotyping was undertaken at the Botanic Gardens and 485 Parks Authority in Perth. We thank G Truong for lepidochronology data, and T Peters, R 486 Neumann, M Garcia-Piza and R Blick for assistance with fieldwork. AR Hughes and JT Wright 487 provided comments that significantly improved the manuscript.

\section{References}

489 Aguirre JD, Marshall DJ (2012) Genetic diversity increases population productivity in a sessile 490 marine invertebrate. Ecology 93:1134-1142 
491 Ainsworth EA, Gillespie KM (2007) Estimation of total phenolic content and other oxidation

492 substrates in plant tissues using Folin-Ciocalteu reagent. Nature Protocols 2:875-877

493 Aires T, Marbà N, Cunha RL, Kendrick GA, Walker DI, Serrão EA, Duarte CM, Arnaud-Haond

494 S (2011) Evolutionary history of the seagrass genus Posidonia. Marine Ecology Progress Series $495 \quad 421: 117-130$

496 Alcoverro T, Manzanera M, Romero J (2001) Annual metabolic carbon balance of the seagrass

497 Posidonia oceanica: the importance of carbohydrate reserves. Marine Ecology Progress Series $498 \quad 211: 105-116$

499 Alpert P, Stuefer JF (1997) Division of labour in clonal plants. In: de Kroon H, van Groenendael $500 \mathrm{~J}$ (eds) The ecology and evolution of clonal plants. Backhuys Publishers, The Netherlands, pp $501 \quad 137-154$

502 Arnaud-Haond S, Belkhir K (2007) GENCLONE: a computer program to analyse genotypic 503 data, test for clonality and describe spatial clonal organization. Molecular Ecology Notes 7: 15$504 \quad 17$

505 Bain KF, Vergés A, Poore AGB (2013) Using near infra red reflectance spectroscopy (NIRS) to 506 quantify tissue composition in the seagrass Posidonia australis. Aquatic Botany 111:66-70

507 Balloux F, Lehmann L, de Meeûs T (2003) The population genetics of clonal and partially clonal 508 diploids. Genetics 164: 1635-1644

509 Barbier ED, Hacker SD, Kennedy C, Koch EW, Stier AC, Silliman BR (2011) The value of 510 estuarine and coastal ecosystem services. Ecological Monographs 81: 169-193 
511 Barton KE, Valkama E, Vehviläinen H, Ruohomäki K, Knight TM, Koricheva J (2015) Additive

512 and non-additive effects of birch genotypic diversity on arthropod herbivory in a long-term field

513 experiment. Oikos 124: 697-706

514 Best RJ, Stone MN, Stachowicz JJ (2015) Predicting consequences of climate change for

515 ecosystem functioning: variation across trophic levels, species and individuals. Diversity and

516 Distributions 21: 1364-1374

517 Bolnick DI, Amarasekare P, Araújo MS, Bürger R, Levine JM, Novak M, Rudolf VHW,

518 Schreiber SJ, Urban MC, Vasseur D (2011) Why intraspecific trait variation matters in

519 community ecology. Trends in Ecology and Evolution 26: 183-192

520 Borowitzka MA, Lavery PS, van Keulen M (2006) Epiphytes of seagrasses. In: Larkum AWD,

521 Orth RJ, Duarte CM (eds) Seagrasses: Biology, ecology and conservation. Springer, The

522 Netherlands, pp 441-461

523 Bradford MA, Wood SA, Bardgett RD, Black HIJ, Bonkowski M, Eggers T, Grayston SJ,

524 Kandeler E, Manning P, Setälä H, Jones TH (2014) Discontinuity in the responses of ecosystem

525 processes and multifunctionality to altered soil community composition. Proceedings of the

526 National Academy of Sciences of the United States of America 111: 14478-14483

527 Byrnes JEK, Gamfeldt L, Isbell F, Lefcheck JS, Griffin JN, Hector A, Cardinale BJ, Hooper DU,

528 Dee LE, Duffy JE (2014) Investigating the relationship between biodiversity and ecosystem

529 multifunctionality: challenges and solutions. Methods in Ecology and Evolution 5: 111-124

530 Callaghan TV, Carlsson BÅ, Jónsdóttir IS, Svensson BM, Jonasson S (1992) Clonal plants and

531 environmental change: introduction to the proceedings and summary. Oikos 63:341-347 
532 Callaway RM, Pennings SC, Richards CL (2003) Phenotypic plasticity and interactions among 533 plants. Ecology 84:1115-1128

534 Cardinale BJ, Gross K, Fritschie K, Flobaum P, Fox JW, Rixen C, van Ruijven J, Reich PB, 535 Scherer-Lorenzen M, Wilsey BJ (2013) Biodiversity simultaneously enhances the production 536 and stability of community biomass, but the effects are independent. Ecology 94:1697-1707

537 Castagneyrol B, Lagache L, Giffard B, Kremer A, Jactel H (2012) Genetic diversity increases 538 insect herbivory on oak saplings. PLoS One 7: e44247

539 Colman JS, Segrove F (1955) The tidal plankton over Stoupe Beck Sands, Robin Hood's Bay 540 (Yorkshire, North Riding). Journal of Animal Ecology 24:445-462

541 Connolly RM (1994) Comparison of fish catches from a buoyant pop net and a beach seine net in 542 a shallow seagrass habitat. Marine Ecology Progress Series 109:305-309

543 Costanza R, d'Arge R, de Groot R, Farber S, Grasso M, Hannon B, Limburg K, Naeem S, 544 O’Neil RV, Paruelo J, Raskin RG, Sutton P, van der Belt M (1997). The value of the world's 545 ecosystem services and natural capital. Nature 387:253-260.

546 Creese RG, Glasby TM, West G, Gallen C (2009) Mapping the habitats of NSW estuaries.

547 Industry \& Investment NSW Fisheries Final Report Series 113. Port Stephens, ISSN 1837-2112

548 Crutsinger GM, Collins MD, Fordyce JA, Gompert Z, Nice CC, Sanders NJ (2006) Plant

549 genotypic diversity predicts community structure and governs an ecosystem process. Science $550 \quad 313: 966-968$ 
551 Drummond EBM, Vellend M (2012) Genotypic diversity effects on the performance of

552 Taraxacam officinale populations increase with time and environmental favorability. PLoS One $553 \quad 7: \mathrm{e} 30314$

554 Duffy JE (2006) Biodiversity and the functioning of seagrass ecosystems. Marine Ecology 555 Progress Series 311: 233-250

556 Duffy JE, Richardson JP, Canuel EA (2003) Grazer diversity effects on ecosystem functioning in 557 seagrass beds. Ecology Letters 6: 637-645

558 Eckert CG (2002) The loss of sex in clonal plants. Evolutionary Ecology 15:501-520

559 Ehlers A, Worm B, Reusch TBH (2008) Importance of genetic diversity in eelgrass Zostera 560 marina for its resilience to global warming. Marine Ecology Progress Series 355:1-7

561 Ellers J (2009) Evolutionary processes in community ecology. In: Verhoef HA, Morin PJ (eds) 562 Community ecology: Processes, models and applications. Oxford University Press, Oxford, pp $563 \quad 151-162$

564 Evans SM, Sinclair EA, Poore AGB, Steinberg PD, Kendrick GA, Vergés A (2014) Genetic 565 diversity in threatened Posidonia australis seagrass meadows. Conservation Genetics 15:717$566 \quad 728$

567 Farina S, Tomas S, Prado P, Romero J, Alcoverro T (2009) Seagrass meadow structure alters 568 interactions between the sea urchin Paracentrotus lividus and its predators. Marine Ecology 569 Progress Series 377:131-137 
570 Foley WJ, McIlwee A, Lawler I, Aragones L, Woolnough AP, Berding N (1998) Ecological

571 applications of near infrared reflectance spectroscopy: A tool for rapid, cost-effective prediction

572 of the composition of plant and animal tissues and aspects of animal performance. Oecologia

$573 \quad 116: 293-305$

574 Forsman A, Wennersten L (2015) Inter-individual variation promotes ecological success of

575 populations and species: evidence from experimental and comparative studies. Ecography 38:

$576 \quad 001-019$

577 Foster Huenneke L (1991) Ecological implications of genetic variation in plant populations. In:

578 Falk DAI, Holsinger KE (eds) Genetics and conservation of rare plants. Oxford University Press, 579 Oxford, pp 31-44

580 Fourqurean JW, Duarte CM, Kennedy H, Marbà N, Holmer M, Mateo MA, Apostolaki ET,

581 Kendrick GA, Krause-Jensen D, McGlathery KJ, Serrano O (2012) Seagrass ecosystems as a 582 globally significant carbon stock. Nature Geoscience 5: 505-509

583 Gobert S, Cambridge ML, Velimirov B, Pergent G, Lepoint G, Bouquegneau J, Dauby P, 584 Pergent-Martini C, Walker DI (2006) Biology of Posidonia. In: Larkum AWD, Orth RJ, Duarte 585 CM (eds) Seagrasses: Biology, ecology and conservation. Springer, The Netherlands, pp 387$586 \quad 408$

587 Goecker ME, Heck KL, Valentine JF (2005) Effects of nitrogen concentrations in turtlegrass 588 Thalassia testudinum on consumption by the bucktooth parrotfish Sparisoma radians. Marine 589 Ecology Progress Series 286:239-248 
590 Greene LE, Alevizon WS (1989) Comparative accuracies of visual assessment methods for coral

591 reef fishes. Bulletin of Marine Science 44:899-912

592 Harrison PG (1989) Detrital processing in seagrass systems: a review of factors affecting decay

593 rates, remineralization and detritivory. Aquatic Botany 35:263-288

594 Hay KB, Millers K, Poore AGB, Lovelock CE (2010). The use of near infrared reflectance

595 spectrometry for characterisation of brown algal tissue traits. Journal of Phycology 46:937-946

596 Heck KL, Valentine JF (2006) Plant-herbivore interactions in seagrass meadows. Journal of 597 Experimental Marine Biology and Ecology 330: 420-436

598 Honnay O, Bossuyt B (2005) Prolonged clonal growth: escape route or route to extinction?

599 Oikos 108: 427-432

600 Hooper DU, Chapin FS, Ewel JJ, Hector A, Inchausti P, Lavorel S, Lawton JH, Lodge DM,

601 Loreau M, Naeem S, Schmid B, Setälä H, Symstand AJ, Vandermeer J, Wardle DA (2005)

602 Effects of biodiversity on ecosystem functioning: a consensus of current knowledge. Ecological

603 Monographs 75:3-35

604 Hughes AR (2014) Genotypic diversity and trait variance interact to affect marsh plant 605 performance. Journal of Ecology 102:651-658.

606 Hughes AR, Best RJ, Stachowicz JJ (2010) Genotypic diversity and grazer identity interactively 607 influence seagrass and grazer biomass. Marine Ecology Progress Series 403:43-51

608 Hughes AR, Inouye BD, Johnson MTJ, Underwood N, Vellend M (2008) Ecological 609 consequences of genetic diversity. Ecology Letters 11:609-623 
610 Hughes AR, Stachowicz JJ (2004) Genetic diversity enhances the resistance of a seagrass

611 ecosystem to disturbance. Proceedings of the National Academy of Sciences of the United States

612 of America 101:8998-9002

613 Hughes AR, Stachowicz JJ (2011) Seagrass genotypic diversity increases disturbance response

614 via complementarity and dominance. Journal of Ecology 99:445-453

615 Hughes AR, Stachowicz JJ, Williams SL (2009) Morphological and physiological variation 616 among seagrass (Zostera marina) genotypes. Oecologia 159:725-733

617 Jahnke M, Olsen JL, Procaccini G (2015) A meta-analysis reveals a positive correlation between 618 genetic diversity metrics and environmental status in the long-lived seagrass Posidonia oceanica.

619 Molecular Ecology 24: 2336-2348

620 Jump AS, Marchant R, Peñuelas J (2009) Environmental change and the option value of genetic 621 diversity. Trends in Plant Science 14: 1360-1385

622 Kendrick GA, Waycott M, Carruthers TB, Cambridge ML, Hovey R, Krauss SL, Lavery PS, Les 623 DH, Lowe RJ, Mascaró O, Ooi Lean Sim J, Orth RJ, Rivers D, Ruiz-Montoya L, Sinclair EA, 624 Statton J, van Dijk K, Verduin J (2012) The central role of dispersal in the maintenance and 625 persistence of seagrass populations. BioScience 62:56-65

627 Kotowska AM, Cahill JF, Keddie BA (2010) Plant genetic diversity yields increased plant 628 productivity and herbivore performance. Journal of Ecology 98:237-245 
629 Lande R, Shannon S (1996) The role of genetic variation in adaptation and population

630 persistence in a changing environment. Evolution 50: 434-437

631 Lefcheck JS, Byrnes JEK, Isbell F, Gamfeldt L, Griffin JN, Eisenhauer N, Hensel MJS, Hector 632 A, Cardinale BJ, Duffy JE (2015) Biodiversity enhances ecosystem multifunctionality across 633 trophic levels and habitats. Nature Communications 6: 6936

634 Loreau M, Naeem S, Inchausti P, Bengtsson J, Grime JP, Hector A, Hooper DU, Huston MA, 635 Raffaelli D, Schmid B, Tilman D, Wardle DA (2001) Biodiversity and ecosystem functioning: 636 current knowledge and future challenges. Science 294:804-808

637 Massa SI, Paulino CM, Serrão EA, Duarte CM, Arnaud-Haond S (2013) Entangled effects of 638 allelic and clonal (genotypic) richness in the resistance and resilience of experimental 639 populations of the seagrass Zostera noltii to diatom invasion. BMC Ecology 13:39-50

640 Mateo MA, Cebrian J, Dunton KH, Mutchler T (2006) Carbon flux in seagrass ecosystems. In: 641 Larkum AWD, Orth RJ, Duarte CM (eds) Seagrasses: Biology, ecology and conservation. 642 Springer, The Netherlands, pp 227-254

643 McArt SH, Thaler JS (2013) Plant genotypic diversity reduces the rate of consumer resource 644 utilization. Proceedings of the Royal Society B 280:20130639

645 McLellan AJ, Prati D, Kaltz O, Schmid B (1997) Structure and analysis of phenotypic and 646 genetic variation in clonal plants. In: de Kroon $H$, van Groenendael J 647 (eds) The ecology and evolution of clonal plants. Backhuys Publishers, The Netherlands, pp 185$648 \quad 210$ 
649 McMahon K, van Dijk K, Ruiz-Montoya L, Kendrick GA, Krauss SL, Waycott M, Verduin J,

650 Lowe R, Statton J, Brown E, Duarte C (2014) The movement ecology of seagrasses. Proceedings

651 of the Royal Society B 281: 20140878

652 Middleton MJ, Bell JD, Burchmore JJ, Pollard DA, Pease BC (1984) Structural differences in 653 fish communities of Zostera capricorni and Posidonia australis seagrass meadows in Botany 654 Bay, New South Wales. Aquatic Botany 18:89-109

655 Miner BG, Sultan SE, Morgan SG, Padilla DK, Relyea RA (2005) Ecological consequences of 656 phenotypic plasticity. Trends in Ecology and Evolution 20:685-692

657 NSW Department of Primary Industries (2012) Endangered populations in NSW: Posidonia 658 australis in Port Hacking, Botany Bay, Sydney Harbour, Pittwater, Brisbane Water and Lake 659 Macquarie. Fisheries Ecosystem Unit, Port Stephens Fisheries Institute, NSW, ISSN: 1832-6668

660 Peirano A (2002) Lepidochronology and intermodal length methods for studying Posidonia 661 oceanica growth: are they compatible? Aquatic Botany 74:175-180

662 Pergent G, Pergent-Martini C, Cambridge M (1997) Morphochronological variations in the 663 genus Posidonia. Marine and Freshwater Research 48:421-424

664 Pergent G, Pergent-Martini C, Fernandez C, Pasqualini V, Walker DI (2004) Morpho665 chronological variations and primary production in Posidonia sea grass from Western Australia. 666 Journal of the Marine Biological Association of the United Kingdom 84:895-899

667 Ralph PJ, Durako MJ, Enriquez S, Collier CJ, Doblin MA (2007) Impact of light limitation on 668 seagrasses. Journal of Experimental Marine Biology and Ecology 350:176-193 
669 Reed DH, Frankham R (2003) Correlation between fitness and genetic diversity. Conservation

670 Biology 17:230-237

671 Reusch TBH (2001) New markers - old questions: population genetics of seagrasses. Marine 672 Ecology Progress Series 211:261-274

673 Reusch TBH, Ehlers A, Hämmerli A, Worm B (2005) Ecosystem recovery after climatic 674 extremes enhanced by genotypic diversity. Proceedings of the National Academy of Sciences of 675 the United States of America 102:2826-2831

676 Schlichting CD (1986) The evolution of phenotypic plasticity in plants. Annual Review of 677 Ecology and Systematics 17: 667-693

678 Short FT, Duarte CM (2001) Methods for the measurement of seagrass growth and production. 679 In: Short FT, Coles RG (eds) Global Seagrass Research Methods. Elsevier Science B.V., The 680 Netherlands, pp. 155-182

681 Sinclair EA, Anthony J, Coupland GT, Waycott M, Barrett MD, Barrett RL, Cambridge ML, 682 Wallace MJ, Dixon KW, Krauss SL, Kendrick GA (2009) Characterisation of polymorphic 683 microsatellite markers in the widespread Australian seagrass, Posidonia australis Hook. f. 684 (Posidoniaceae), with cross-amplification in the sympatric P. sinuosa. Conservation Genetics 685 Resources 1:273-276

686 Singleton VL, Orthofer R, Lamuela-Raventós RM (1999) Analysis of total phenols and other 687 oxidation substrates and antioxidants by means of Folin-Ciocalteu reagent. Methods in 688 Enzymology 299:152-178 
689 Stachowicz JJ, Bruno JF, Duffy JE (2007) Understanding the effects of marine biodiversity on 690 communities and ecosystems. Annual Review of Ecology Evolution and Systematics 38:739-66

691 Stomp M, van Dijk MA, van Overzee HMJ, Wortel MT, Sigon CAM, Egas M, Hoogveld H, 692 Gons HJ, Huisman J (2008) The timescale of phenotypic plasticity and its impact on competition 693 in fluctuating environments. American Naturalist 172:E169-E185

694 Tilman D, Reich PB, Isbell F (2012) Biodiversity impacts ecosystem productivity as much as 695 resources, disturbance, or herbivory. Proceedings of the National Academy of Sciences of the 696 United States of America 109:10394-10397

697 Tomas F, Abbott JM, Steinberg C, Balk M, Williams SL, Stachowicz JJ (2011) Plant genotype 698 and nitrogen loading influence seagrass productivity, biochemistry, and plant-herbivore 699 interactions. Ecology 92:1807-1817

700 Unsworth RKF, van Keulen M, Coles RG (2014) Seagrass meadows in a globally changing 701 environment. Marine Pollution Bulletin 83:383-386

702 Valentine JF, Duffy JE (2006) The central role of grazing in seagrass ecology. In: Larkum AWD, 703 Orth RJ, Duarte CM (eds) Seagrasses: Biology, ecology and conservation. Springer, The 704 Netherlands, pp 463-501

705 Valladares F, Gianoli E, Gómez JM (2007) Ecological limits to phenotypic plasticity. New 706 Phytologist 176:749-763 
707 Vasemägi A, Primmer CR (2005) Challenges for identifying functionally important genetic

708 variation: the promise of combining complementary research strategies. Molecular Ecology 14:

$709 \quad 3623-3642$

710 Vergés A, Becerro MA, Alcoverro T, Romero J (2007) Experimental evidence of chemical

711 deterrence against multiple herbivores in the seagrass Posidonia oceanica. Marine Ecology

712 Progress Series 343:107-114

713 Wardle DA (1999) Is sampling effect a problem for experiments investigating biodiversity-

714 ecosystem function relationships? Oikos 87:403-407

715 Waycott M, Duarte CM, Carruthers TJB, Orth RJ, Dennison WC, Olyarnik S, Calladine A,

716 Fourqurean JW, Heck KL, Hughes AR, Kendrick GA, Kenworthy WJ, Short FT, Williams SL

717 (2009) Accelerating loss of seagrasses across the globe threatens coastal ecosystems.

718 Proceedings of the National Academy of Sciences of the United States of America 106:12377-

71912381.

720 Waycott M, Longstaff BJ, Mellors J (2005) Seagrass population dynamics and water quality in

721 the Great Barrier Reef region: A review and future research directions. Marine Pollution Bulletin $722 \quad 51: 343-350$.

723 West RJ (2012) Impacts of recreational boating activities on the seagrass Posidonia in SE

724 Australia. Wetlands (Australia) 26:3-13.

725 Whitham TG, Bailey JK, Schweitzer JA, Shuster SM, Bangert RK, LeRoy CJ, Lonsdorf EV, 726 Allan GJ, DiFazio SP, Potts BM, Fischer DG, Gehring CA, Lindroth RL, Marks JC, Hart SC, 
727 Wimp GM, Wooley SC (2006) A framework for community and ecosystem genetics: from genes 728 to ecosystems. Nature Reviews Genetics 7:510-523.

729 Wood N, Lavery P (2000) Monitoring seagrass ecosystem health - the role of perception in 730 defining health and indicators. Ecosystem Health 6:134-148. 


\section{Tables and Figures}

732 Table 1. Frequency of the seven shared multilocus genotypes (MLGs) originally identified in 733 Evans et al. (2014). These seven MLGs are arbitrarily named using the letters A to G. The 734 frequency with which they occur in each meadow is shown in the columns titled ' $\mathrm{N}$ per 735 meadow'. The meadows in which these shared genotypes are found are listed. All remaining 736 MLGs not listed were unique to their sample location. Four meadows not listed here contained 737 only unique MLGs.

738

\begin{tabular}{|c|c|c|c|c|c|c|c|c|}
\hline \multirow{2}{*}{ MLG } & \multirow{2}{*}{$\begin{array}{c}\text { Total } \\
\mathbf{N}\end{array}$} & \multicolumn{7}{|c|}{$\mathbf{N}$ per meadow } \\
\hline & & $\begin{array}{l}\text { Wallis } \\
\text { Lake }\end{array}$ & $\begin{array}{c}\text { Port } \\
\text { Stephens }\end{array}$ & $\begin{array}{c}\text { Lake } \\
\text { Macquarie }\end{array}$ & $\begin{array}{c}\text { Brisbane } \\
\text { Water }\end{array}$ & Pittwater & $\begin{array}{c}\text { Sydney } \\
\text { Harbour }\end{array}$ & $\begin{array}{c}\text { Botany } \\
\text { Bay }\end{array}$ \\
\hline $\mathrm{A}$ & 56 & 29 & & 27 & & & & \\
\hline B & 2 & 1 & & 1 & & & & \\
\hline $\mathrm{C}$ & 21 & & 13 & & & 8 & & \\
\hline $\mathrm{D}$ & 11 & & 7 & & & 2 & & 2 \\
\hline $\mathrm{E}$ & 4 & & & 2 & & & & 2 \\
\hline $\mathrm{F}$ & 29 & & & & 28 & & 1 & \\
\hline $\mathrm{G}$ & 21 & & & & & 20 & & 1 \\
\hline
\end{tabular}

739 
746

Table 2. The percentage of variation attributable to environment (meadow) and genotype for (a) the genotypes (A and C) that were shared between locations, and (b) for the two locations in which several replicated genotypes occurred (four within Port Stephens and two within Pittwater). For each trait, the percentage of variation explained by the factor and the residual (other) was calculated from least squares variance components following one way ANOVA. Significant effect of the ANOVAs $(P$-values $<0.05)$ are in bold. Asterisks represent missing data.

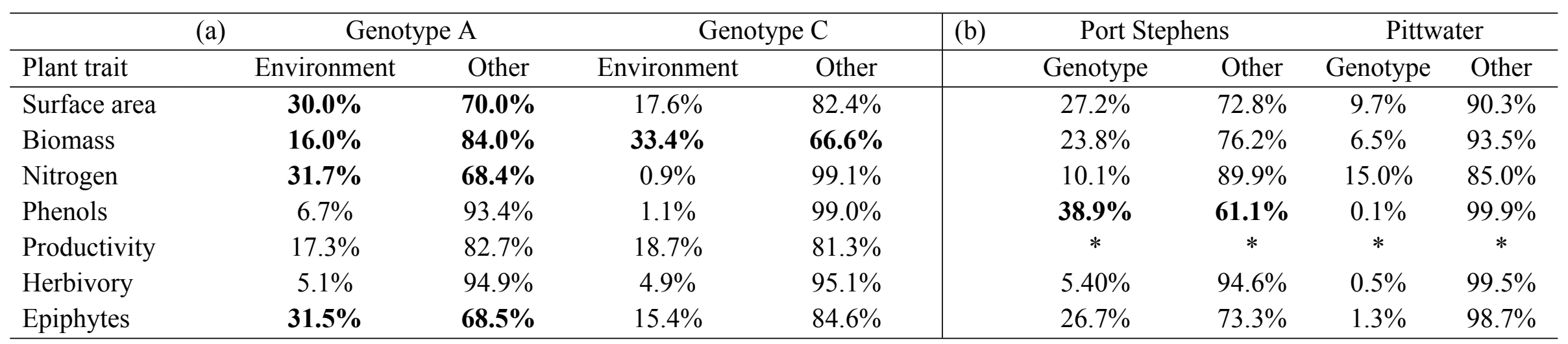




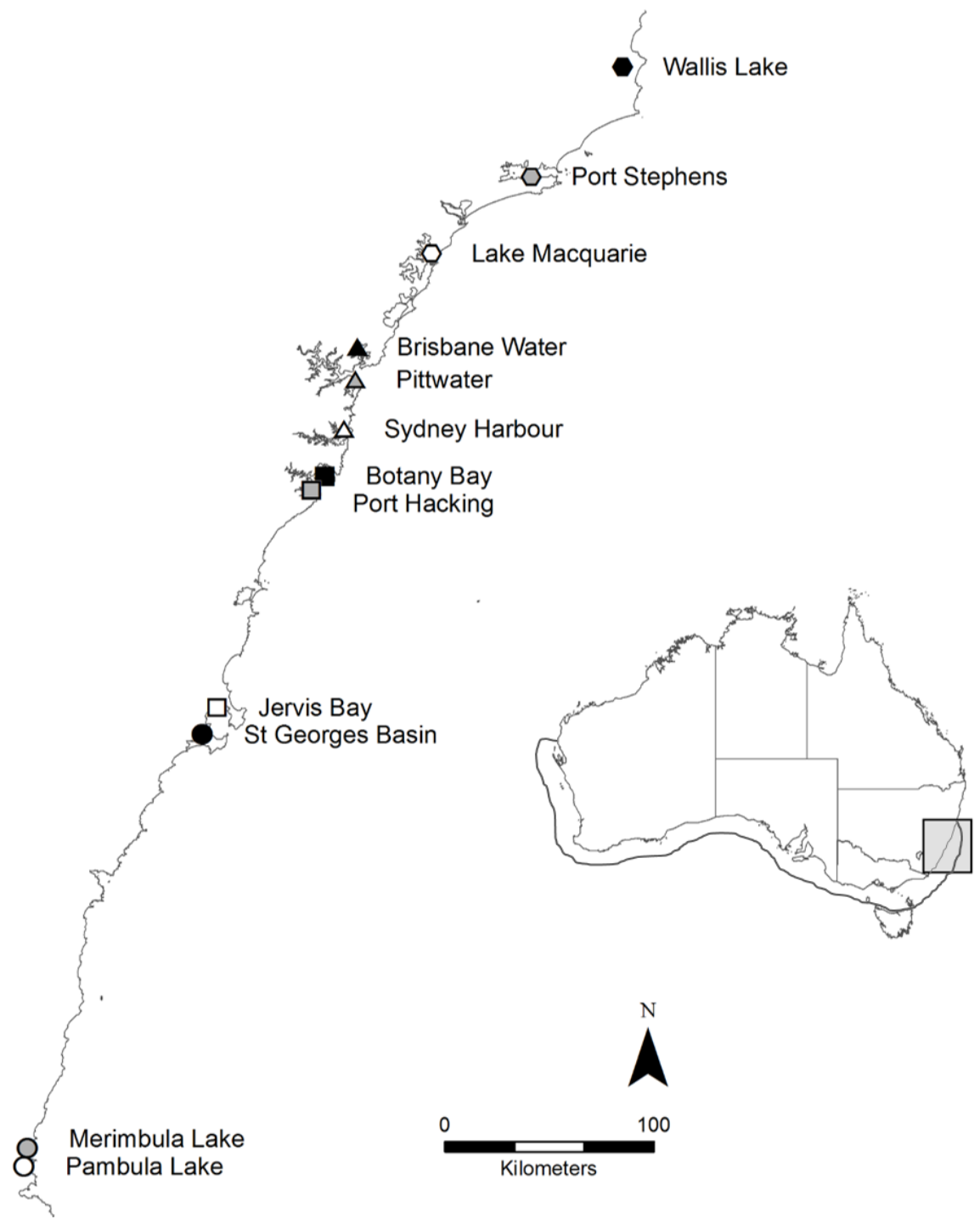

750 Fig. 1. Map of the twelve sample locations in New South Wales, Australia. The full distribution 751 of $P$. australis is represented by the outline on the inlaid map. The $\sim 600 \mathrm{~km}$ of coastline sampled 752 on along the east coast is highlighted by the light grey box.

753

754

755

756 
a) surface area

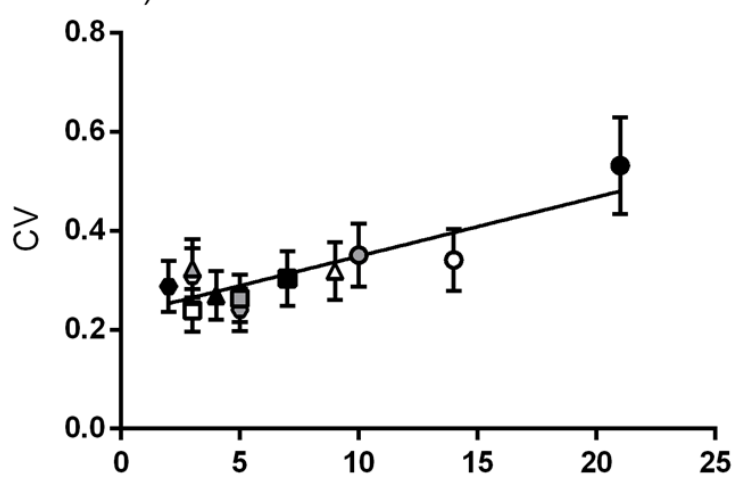

b) biomass

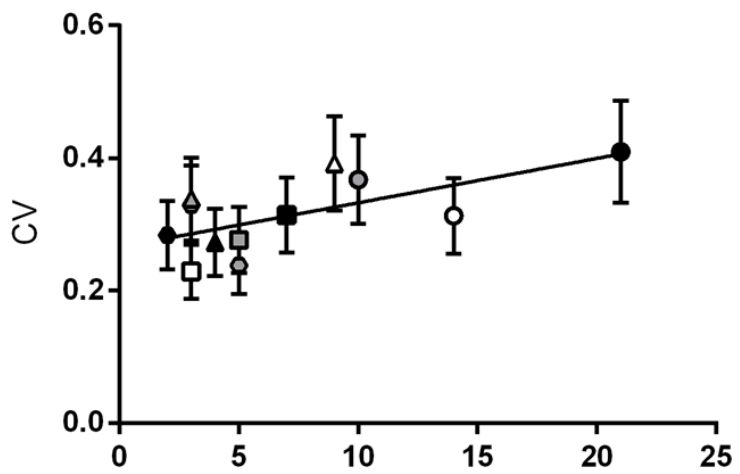

c) chemical constituents

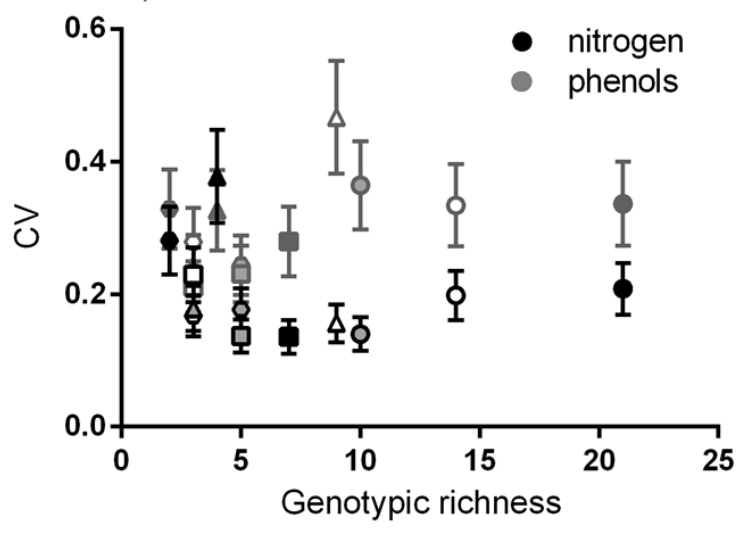

757

758

759

760

761

762

763

764

Fig. 2. The relationship between genotypic richness and phenotypic dissimilarity (measured as the coefficient of variation or CV) for (a) surface area $\left(\mathrm{mm}^{2}\right.$ shoot $\left.^{-1}\right)$; (b) biomass (mg dw shoot ${ }^{1}$ ); and (c) chemical constituents (GAE \% dw shoot ${ }^{-1}$ ). Significant relationships from linear regression were found between genotypic richness and the coefficients of variation for surface area $\left(\mathrm{a} ; \mathrm{R}^{2}=0.75, P<0.001\right)$ and shoot biomass $\left(\mathrm{b} ; \mathrm{R}^{2}=0.43, P=0.02\right)$. There were no significant relationships between genotypic richness and the coefficients of variation for nitrogen 
765 or phenols (c; $\mathrm{R}^{2}=0.04, P=0.56 ; \mathrm{R}^{2}=0.20, P=0.15$, respectively). Different symbols

766 correspond to individual meadows sampled (see Fig. 1).

767

768

a) productivity

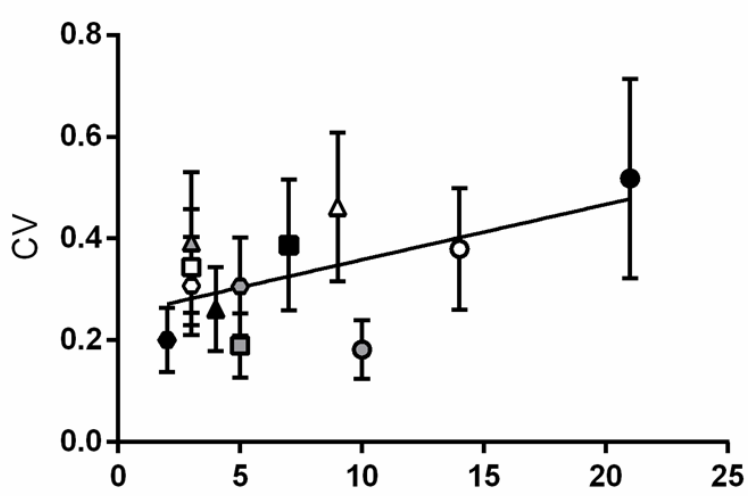

b) epiphytes

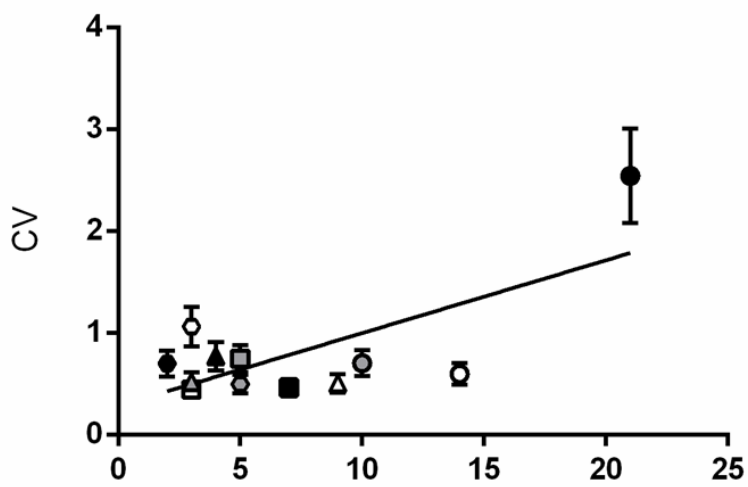

c) herbivory

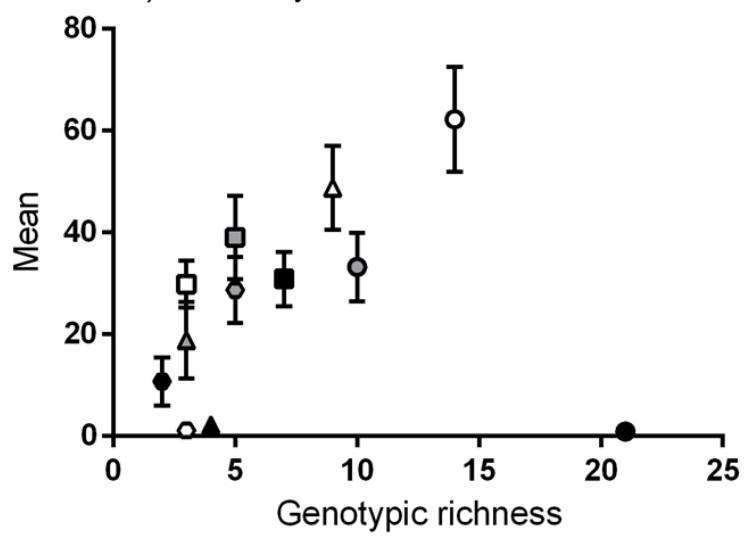

Fig. 3. The relationships between genotypic richness and (a) mean coefficient of variation for 
$772 \mathrm{dw}$ shoot $\left.{ }^{-1}\right)$; and (c) mean herbivory $\left(\mathrm{mm}^{2}\right.$ shoot $\left.^{-1}\right)$. There was a significant relationship between 773 genotypic richness and mean coefficient of variation for both productivity $\left(\mathrm{b} ; \mathrm{R}^{2}=0.32, P=\right.$ 7740.05 ) and epiphyte biomass ( $\mathrm{a} ; \mathrm{R}^{2}=0.48, P=0.02$ ). There was no significant linear relationship 775 between mean herbivory and genotypic richness $\left(\mathrm{R}^{2}=0.03, P=0.6\right)$. Different symbols 776 correspond to individual meadows sampled (see Fig. 1). 


\section{Table $\mathbf{1}$ (on next page)}

Frequency of the seven shared multilocus genotypes in New South Wales meadows

Table 1. Frequency of the seven shared multilocus genotypes (MLGs) originally identified in Evans et al. (2014). These seven MLGs are arbitrarily named using the letters A to G. The frequency with which they occur in each meadow is shown in the columns titled ' $\mathrm{N}$ per meadow'. The meadows in which these shared genotypes are found are listed. All remaining MLGs not listed were unique to their sample location. Four meadows not listed here contained only unique MLGs. 


\begin{tabular}{|c|c|c|c|c|c|c|c|c|}
\hline \multirow{2}{*}{ MLG } & \multirow{2}{*}{$\begin{array}{c}\text { Total } \\
\mathbf{N}\end{array}$} & \multicolumn{7}{|c|}{ N per meadow } \\
\hline & & $\begin{array}{l}\text { Wallis } \\
\text { Lake }\end{array}$ & $\begin{array}{c}\text { Port } \\
\text { Stephens }\end{array}$ & $\begin{array}{c}\text { Lake } \\
\text { Macquarie }\end{array}$ & $\begin{array}{c}\text { Brisbane } \\
\text { Water }\end{array}$ & Pittwater & $\begin{array}{c}\text { Sydney } \\
\text { Harbour }\end{array}$ & $\begin{array}{c}\text { Botany } \\
\text { Bay }\end{array}$ \\
\hline $\mathrm{A}$ & 56 & 29 & & 27 & & & & \\
\hline B & 2 & 1 & & 1 & & & & \\
\hline $\mathrm{C}$ & 21 & & 13 & & & 8 & & \\
\hline $\mathrm{D}$ & 11 & & 7 & & & 2 & & 2 \\
\hline $\mathrm{E}$ & 4 & & & 2 & & & & 2 \\
\hline $\mathrm{F}$ & 29 & & & & 28 & & 1 & \\
\hline $\mathrm{G}$ & 21 & & & & & 20 & & 1 \\
\hline
\end{tabular}

1 


\section{Table 2 (on next page)}

Percentage of variation attributable to environment and genotype

Table 2. The percentage of variation attributable to environment (meadow) and genotype for (a) the genotypes ( $A$ and $C$ ) that were shared between locations, and (b) for the two locations in which several replicated genotypes occurred (four within Port Stephens and two within Pittwater). For each trait, the percentage of variation explained by the factor and the residual (other) was calculated from least squares variance components following one way ANOVA. Significant effect of the ANOVAs ( $P$-values $<0.05$ ) are in bold. Asterisks represent missing data. 


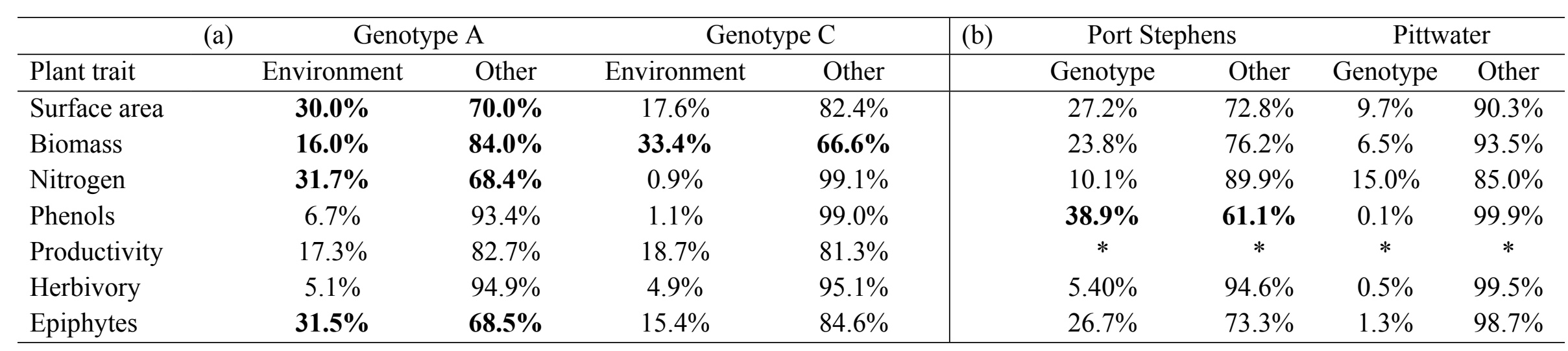




\section{1}

Map of the twelve sample locations in New South Wales, Australia

Fig. 1. Map of the twelve sample locations in New South Wales, Australia. The full distribution of $P$. australis is represented by the outline on the inlaid map. The $\sim 600 \mathrm{~km}$ of coastline sampled on along the east coast is highlighted by the light grey box.

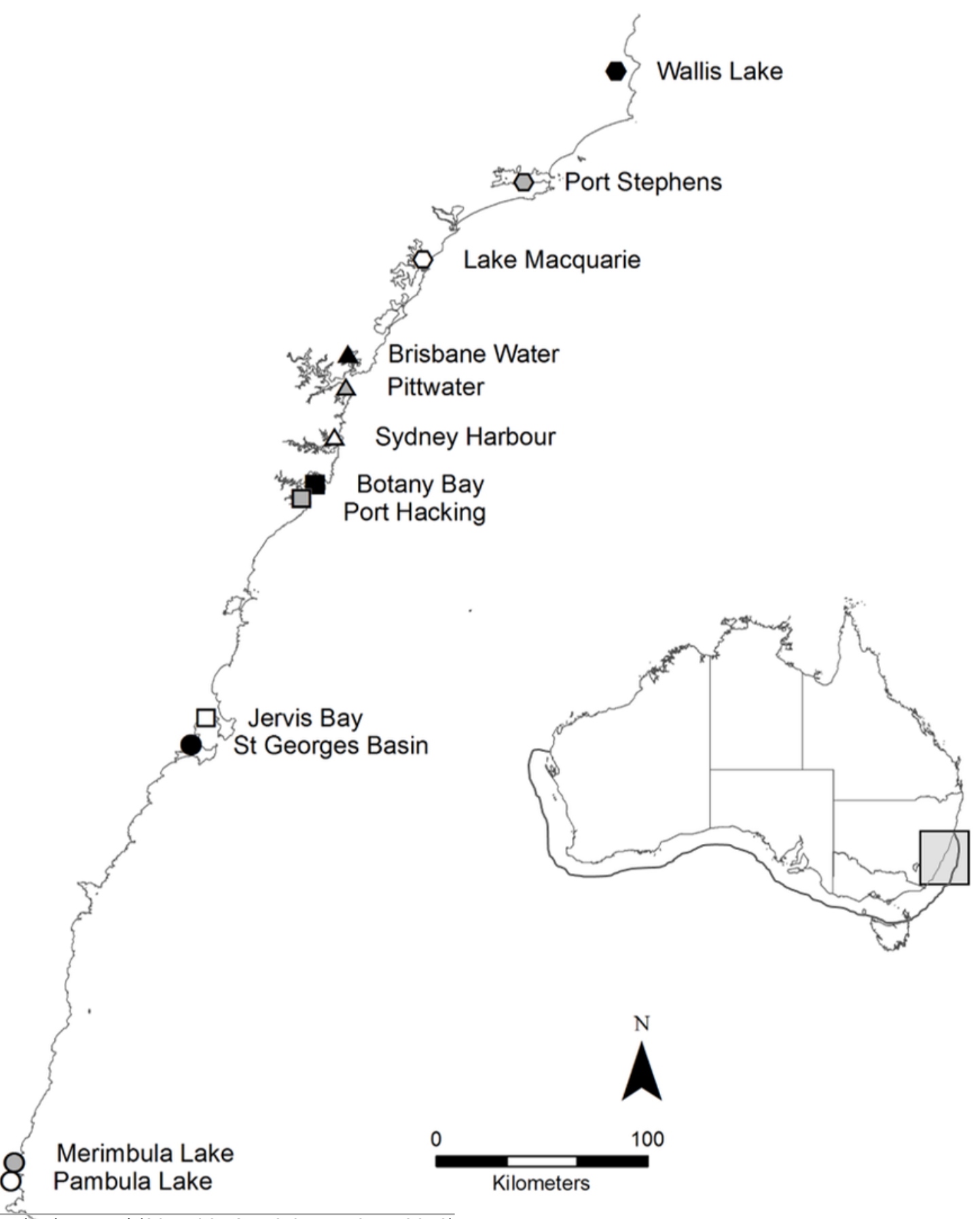


2

Relationship between genotypic richness and variation in surface area, biomass and chemical constituents

Fig. 2. The relationship between genotypic richness and phenotypic dissimilarity (measured as the coefficient of variation or CV) for (a) surface area $\left(\mathrm{mm}^{2}\right.$ shoot $\left.^{-1}\right)$; (b) biomass ( $\mathrm{mg} \mathrm{dw}$ shoot ${ }^{-1}$ ); and (c) chemical constituents (GAE \% dw shoot ${ }^{-1}$ ). Significant relationships from linear regression were found between genotypic richness and the coefficients of variation for surface area $\left(a ; R^{2}=0.75, P<0.001\right)$ and shoot biomass $\left(b ; R^{2}=0.43, P=0.02\right)$. There were no significant relationships between genotypic richness and the coefficients of variation for nitrogen or phenols ( $c ; \mathrm{R}^{2}=0.04, P=0.56 ; \mathrm{R}^{2}=0.20, P=0.15$, respectively). Different symbols correspond to individual meadows sampled (see Fig. 1). 
a) surface area

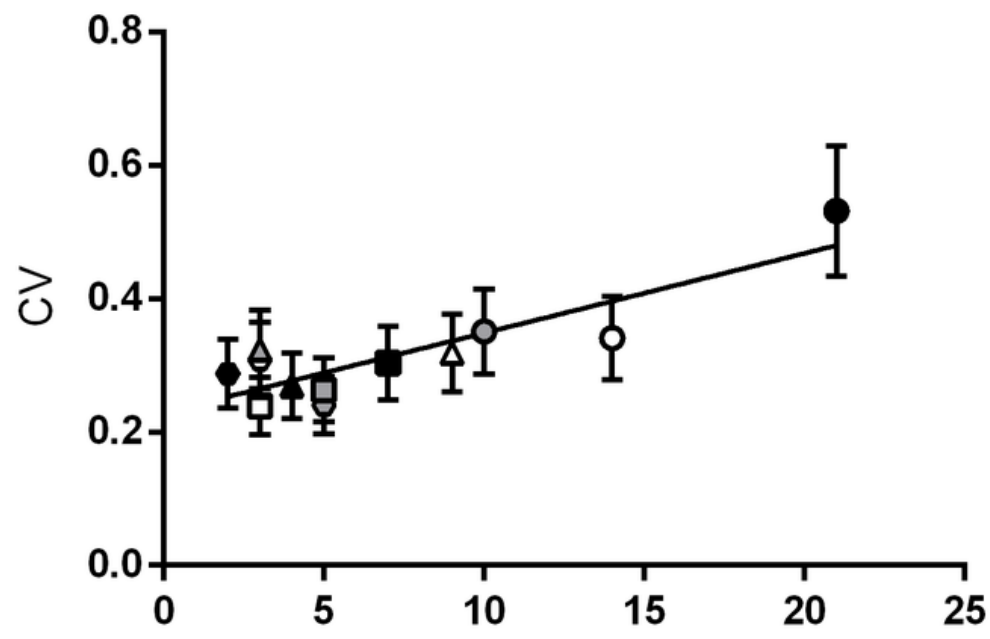

b) biomass

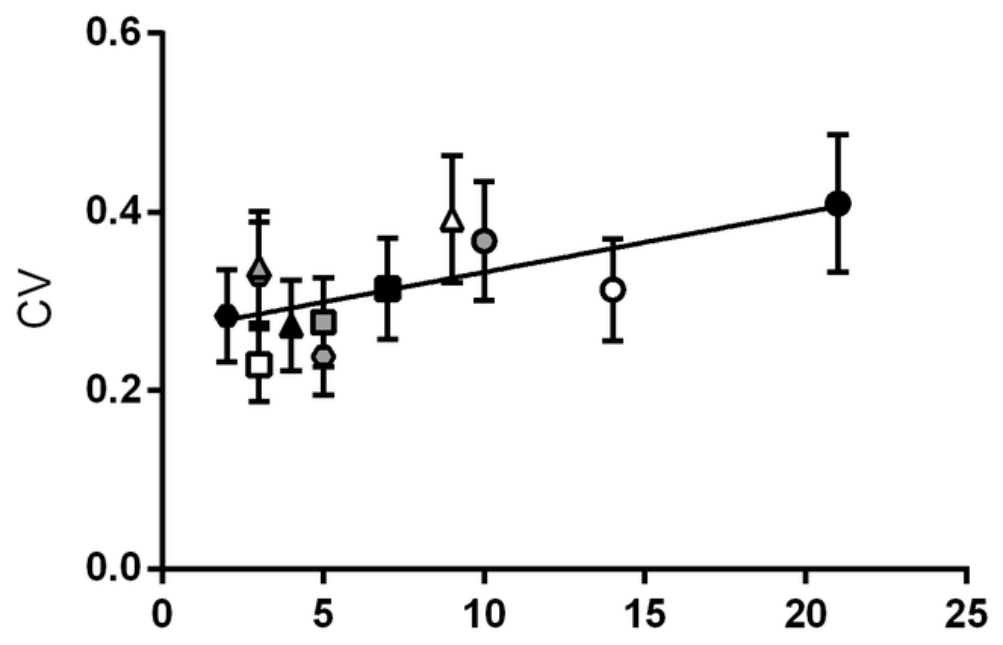

c) chemical constituents

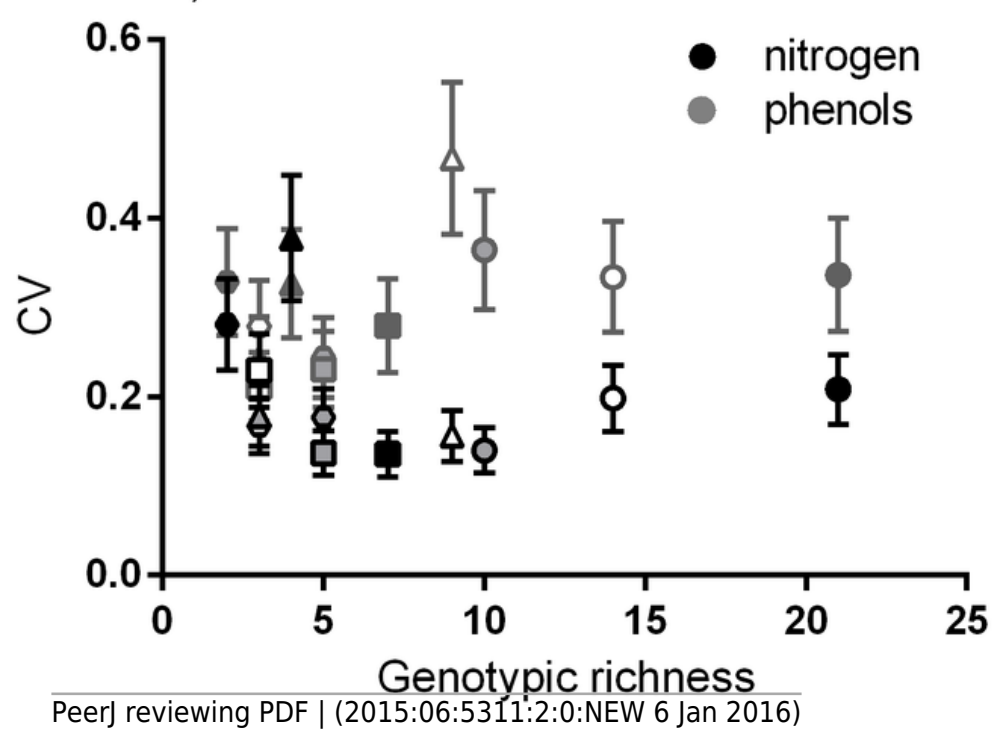


3

Relationships between genotypic richness and variation in productivity, variation in epiphyte biomass and mean herbivory

Fig. 3. The relationships between genotypic richness and (a) mean coefficient of variation for productivity ( $m g ~ d w ~$ shoot $^{-1}$ year ${ }^{-1}$ ); (b) mean coefficient of variation for epiphyte biomass ( $\left.\mathrm{mg} \mathrm{dw}_{\text {shoot }}\right)^{-1}$; and (c) mean herbivory $\left(\mathrm{mm}^{2}\right.$ shoot ${ }^{-1}$ ). There was a significant relationship between genotypic richness and mean coefficient of variation for both productivity ( $b ; R^{2}=$ $0.32, P=0.05)$ and epiphyte biomass ( $a ; R^{2}=0.48, P=0.02$ ). There was no significant linear relationship between mean herbivory and genotypic richness $\left(R^{2}=0.03, P=0.6\right)$. Different symbols correspond to individual meadows sampled (see Fig. 1). 
a) productivity

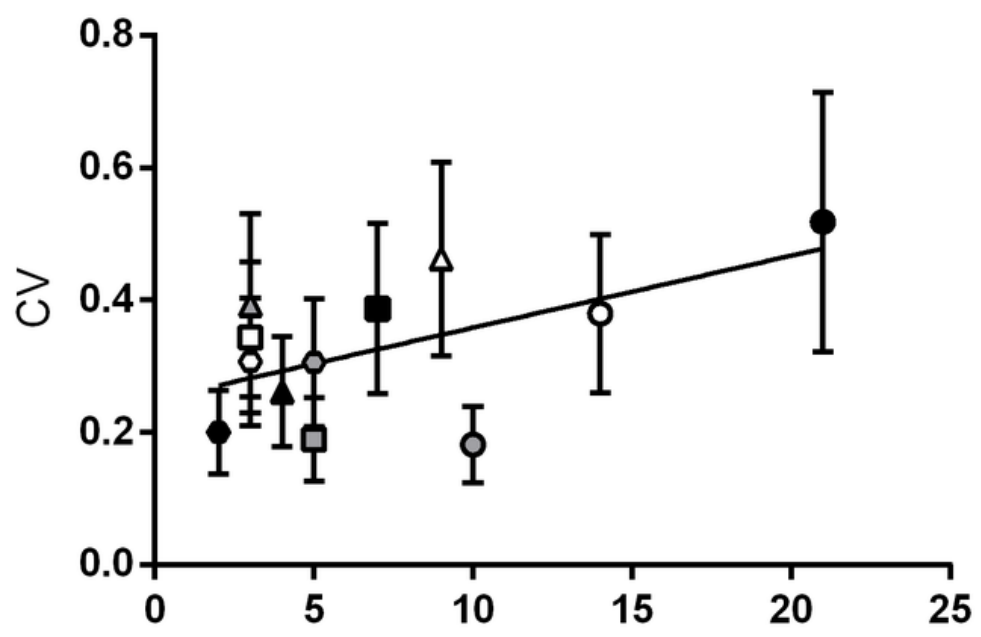

b) epiphytes

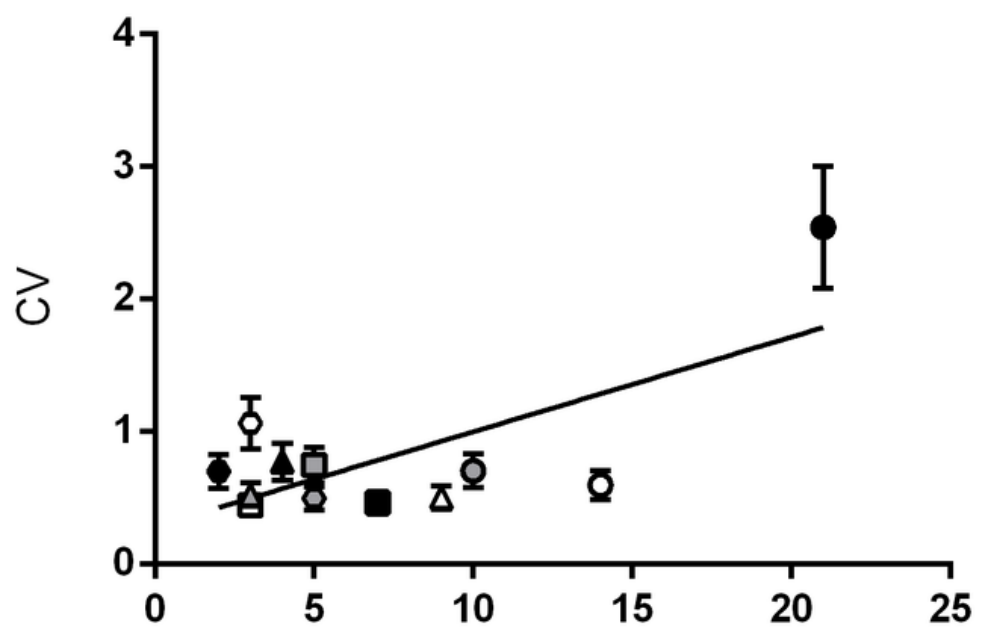

c) herbivory

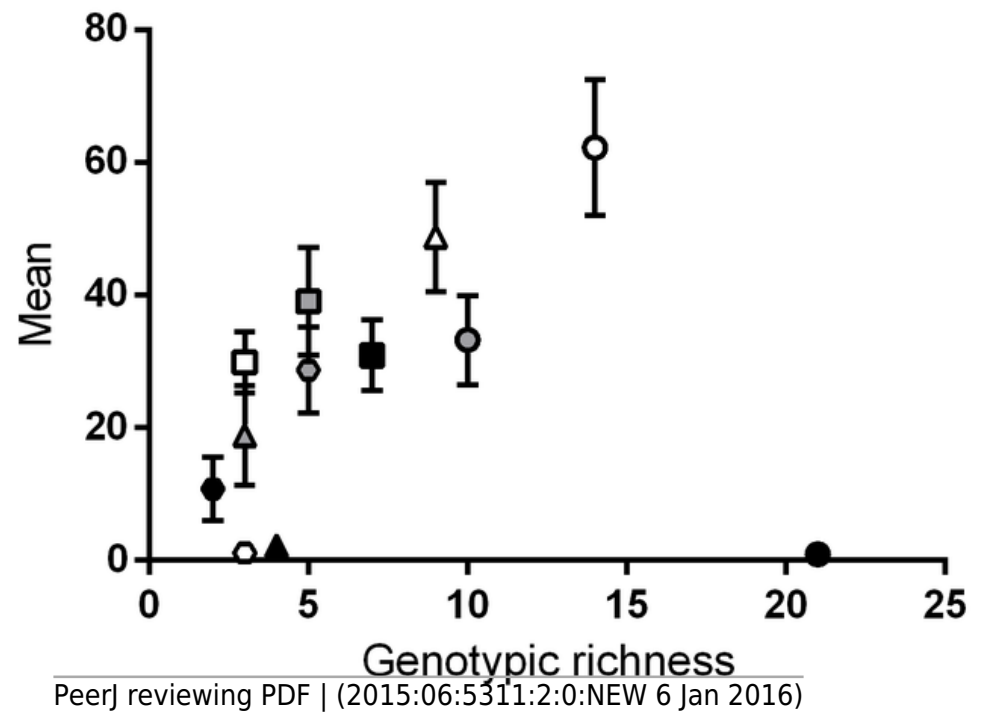

